\title{
LANDSCAPES OF WAR: RULES AND CONVENTIONS OF CONFLICT IN ANCIENT HAWAI'I (AND ELSEWHERE)
}

\author{
Michael J. Kolb and Boyd Dixon
}

\begin{abstract}
A comparison of the rich ethnohistoric record of prehistoric conflict in Hawai' $i$ with evidence of warfare in other culture areas suggests some basic similarities in cause and effect shared by many complex hegemonic polities. Three types of archaeological remains in Hawai' i indicate that human sacrifice and monumental-scale ritual construction were integral parts of pre-Contact (A.D. 1778) conquest warfare. The Hawailans, however, invested much less labor in long-term responses to possible threats to civilian security than many cultures, suggesting that wartime expectations were very different even if the scale and intensity of combat was similar. These differences are perceived to be a reflection of distinct historical traditions of wartime ethics in Polynesia, unique rules of conflict adapted to the geographic isolation of the Hawaiian people and the environmental diversity that defines the archipelago.
\end{abstract}

Con base en una comparación del abundante registro etnohistórico referente a los conflictos prehistóricos en Hawai'i con la evidencia de guerras en otras culturas, se proponen algunas similitudes básicas en su causa y efecto entre muchas culturas hegemónicas complejas. En Hawai i hay tres tipos de restos arqueológicos que indican que el sacrificio humano y la construcción ritual a: una escala monumental formaban parte integral de las contiendas bélicas de conquista previas a la época del contacto (I778 d.C.). Sin embargo, los hawaiianos invirtieron mucho menos trabajo en la respuesta a largo plazo a las posibles amenazas a la seguridad civil que muchas culturas, lo cual sugiere que las expectativas en periodos de guerra fueron muy diferentes, aun cuando la escala e intensidad fueron similares. Estas diferencias se interpretan como un reflejo de tradiciones históricas distintivas acerca de la ética de guerra en Polinesia, reglas particulares de combate adaptadas al aislamiento geográfico de los grupos hawaiianos y la diversidad ambiental que define al archipiélago.

$\mathrm{T}$ The discussion of warfare reported here is the result of ongoing discourse regarding the causes and consequences of social conflict as a means of creating opportunity for local leaders to consolidate authority. Warfare is an ancient phenomenon with a long evolutionary trajectory (see Ferguson 1998; Haas 1990; Keely 1996; Maschner and Reedy-Maschner 1998; Webster 2000 for recent reviews). Warfare and violence are well documented in both ethnographic and archaeological contexts and are particularly endemic among stratified societies (i.e., Johnson and Earle 1987). The typical correlates of warfare include skeletal evidence of violence, weaponry, iconographic depictions, and the presence of fortifications. Although theorists have minimized the role of warfare in chiefly formation for many years (see Carneiro 1990:190), it is now more generally accepted that ritualized conflict and status rivalry are very important for understanding the histories of complex societies (Carneiro 1970, 1981, 1990; Earle 1997; Feinman and Neitzel 1984; Redmond 1994; Webster 1985). Of particular comparative significance are the patterns of status rivalry warfare that the Hawaiian test case offers.

Archaeologists seeking hints about patterns of ancient warfare frequently review and cite Polynesian ethnographic accounts of warfare. For example, David Webster $(1998,2000)$ uses Polynesian accounts to examine Maya warfare and persuasively argues that status rivalry and territorial aggrandizement are complementary rather than mutually exclusive engagement strategies. He also urges consideration of the fact that archaeological manifestations of warfare do not fully mirror the nuances and expressions of strategies that can guide social change. Webster's point is well taken and encouraged

Michael J. Kolb a Department of Anthropology, Northern Illinois University, DeKalb, IL 601 15-2854; aloha@ niu.edu Boyd Dixon - AMEC Earth and Environmental, 680 Iwilei Road, Suite 660, Honolulu, HI 96817; dixonboyd@hotmail.com 
us to go back and review the Hawaiian ethnographic and archaeological literature for more detailed subtleties relevant to a test case where warfare was endemic, yet few permanent fortifications existed. Our goal here is to critically analyze and integrate both ethnographic data and archaeological manifestations regarding status rivalry and the ritual aspects of warfare in order to provide a more accurate picture of warfare in this region. We argue that the archaeological landscape contains additional evidence of warfare not usually considered by archaeologists. These data should prove useful for those interested in using the Hawaiian test case as a springboard for discussions of ancient warfare elsewhere in world prehistory.

Warfare was a highly conspicuous aspect of all Polynesian societies, the majority of evidence being documented in oral histories (best summarized by Earle 1997:131-137; Goldman 1970; Kirch 1984:195). The style and essence of conflicts varied according to economic, demographic, and political factors, ranging from simple raiding parties for gaining social status, to conflicts over resources, to rebellions or struggles for succession, and to large-scale integrative wars between major political powers. The roots of Polynesian conflict are probably ancient; they seem to lie in the social inequalities inherent in formative or "ancestral Polynesian society" when it first evolved from its Lapita progenitor (Kirch 1984:49). A highly stratified social order segmented into competing lines created the pretext for conflicts of all kinds and with profound political overtones. Religious ceremonies, public pronouncements, large-scale sacrificial offerings, displays of status, and competitive rivalry accompanied most battles.

Warfare in ancient Hawai'i (before European contact in A.D. 1778) was a primary tool for political centralization. For centuries before European contact, ritualized combat, armed expeditions of conquest, and chiefly aggrandizement played integral parts of hegemonic territorial expansion. The ethnohistoric record is teeming with references regarding the politics of warfare and violent conflict (' $\overline{\mathbf{I}}$ ' 1963; Kalakaua 1988; Kamakau 1961, 1964, 1976; Malo 1951), while the archaeological record of ancient warfare, as described below, has often been overlooked. High chiefs sought to expand territorial control, eliminate rivals, and integrate current holdings whenever feasible. Their desire was to increase their productive resources by subsuming the agri- cultural fields and commoner labor pool of rivals, thus strengthening the financial foundations of their territory (Hommon 1986).

Despite the plethora of ethnographic data, the archaeological manifestations of warfare in Hawai' $i$ before European contact have not been a major focus of attention due in part to a lack of direct material evidence (Earle 1997:134; Kirch 1990a). The typical archaeological correlates of warfare are generally lacking; occasional discoveries may include a stone club (see Buck 1964), a cluster of sling stones, or a rare find of a wooden war-god statue (Cox and Davenport 1988). We, however, argue that the archaeological landscape holds additional clues to the ritualization of warfare, including such things as wartime places of refuge (Kirch 1984; Schoenfelder 1992), subtle variations in war temple construction (Kolb 1991, 1992, 1994; Kolb and Radewagen 1997), uninhabited "buffer zones" (Cordy 1981:180), and formalized regional patterns of colonization and settlement (Dixon et al. 1995). These phenomena played an important role in defining the accepted social parameters of Hawaiian conflict-parameters that bear some fundamental differences to other regions of the world.

We begin our analysis by presenting an ethnohistoric overview of literature for Hawai' i. Next, we discuss the archaeological manifestations of warfare upon the settlement landscape: the construction of war temples (or heiau luakini), the creation of refuge places (called pu'uhonua), settlement patterns, and buffer zones, and the modification and use of lava tubes as refuge caves. Finally, we define some key characteristics regarding the Hawaiian landscape of war and make some general comparisons to other areas of the world in order to better understand the implications of ancient conflict and its avoidance.

\section{Ethnohistorical Evidence of Warfare}

The Hawaiian ethnohistoric record consists of native histories and Hawaiian kingdom land-tenure documents, as well as European explorer and missionary accounts and early ethnographic observations. These records are filled with descriptions and discussions of chiefly warfare in the islands, both before and after European contact. Native testimonies are records provided by Hawaiian aristocrats who were alive before Euroamerican missionaries arrived in 1820 (e.g., Kamakau 1961, 1976). Land-tenure documents and Hawaiian newspapers date to the nine- 
teenth century. European and American sources consist of personal observations and those of local informants recorded by early explorers and sailors (e.g., Clerke 1967; Ellis 1782; Menzies 1920). Early European and American settlers also synthesized and preserved oral traditions (e.g., Fornander 1969; Lyons 1875), recorded native family traditions (e.g., Ashdown 1979; Fleming 1933), and made early twentieth-century archaeological inventories (e.g., Walker 1931).

\section{Primogenesis of Hawaiian Warfare}

The primogenitors of ancient Hawaiian culture are assumed to have emigrated from an ancestral homeland, most probably in the central Polynesian islands of the Marquesas and/or Tahiti. The date for the colonization of Hawai' i may have been as early as A.D. 100-300 (Emory 1968; Hunt and Holsen 1991; Kirch 1985; Sinoto 1970) or as late as A.D. 800-1000 (Athens and Ward 1993; Spriggs and Anderson 1993; Tuggle and Spriggs 2001), depending largely on the interpretation of paleoenvironmental data. Ethnohistoric literature describes a later period of voyaging to and from a mythical place called "Kahiki" around the thirteenth century A.D. (Emerson 1893; Fornander 1969). During this period, a "Kahikian" priest named $\mathrm{Pa}$ ' ao may have introduced the concept of war temples, a more strict royal taboo system of social sanctions (called the kapu system), a recognized paramount ruler (called ali'i nui or mo'i) of each island, and the god Küka'ilimoku who later became intimately associated with warfare (Hommon 1986). Since this period of contact has not been positively identified in the archaeological record (e.g., Cordy 1974a, 1974b; Dye 1994; Emory and Sinoto 1965; Masse et al. 1991), these aspects of Hawaiian culture and the inception of warfare may instead be in situ developments.

The Hawaiian cultural sequence has been further subdivided into a series of at least four developmental stages (Cordy 1974a; Kirch 1985; Kolb 1994). The sequence begins with initial settlement along windward coastlines of the largest islands up until A.D. 600 , followed by a gradual development of the unique aspects of Hawaiian culture by A.D. 1100. A period of more rapid population expansion into the interior of all islands then followed until about A.D. 1650, after which time the beginnings of true state-level polities accompanied by interpolity warfare were appearing on several islands when Cap- tain Cook arrived in 1778 (Hommon 1976). Armed combat before approximately A.D. 1650 is alluded to in the ethnohistoric record, but not on the scale found at contact.

The structure of Hawaiian society at contact contained two major hierarchical levels of social status (Davenport 1994): (1) the chiefly class (or ali' $i$ ) with several levels of internal ranking based on familial ties and function, and (2) the vast majority of commoners (or maka'ainana). Interaction or exchange between these social levels was considered to be primarily from the bottom up (Earle 1977, 1987), consisting of periodic tribute payment from the commoners to the chiefs in the form of perishable foodstuffs, finished products, and labor in exchange for certain ritual obligations (Kame'eleihiwa 1992). By A.D. 1650 (Hommon 1986), such exchange was mobilized through a unique system of land tenure and use rights that may have been formalized centuries before. The custom was to redistribute land among loyal retainers by senior chiefly lines, resulting in the division of each island into large political districts (or moku) that were further subdivided into communities (or ahupua' a), each community ideally being a pie-shaped parcel of land incorporating both coastal and inland resources. Each community was then managed by a local land manager (or konohiki) of the ruling chief (Malo 1951) who was responsible for exacting tribute from the commoners under his jurisdiction through the allotment of individual farming plots (called 'ili' 'aina). The localized abundance of resources enabled chiefs to shift the residence of their court within and between districts, supporting themselves and their retainers with the tribute provided by the land manager while enlisting commoners as laborers in the large-scale construction of temples, fishponds, agricultural field systems, and taro ponds-and as warriors and field support in times of conflict.

The gap between chief and commoner at the time of contact was quite vivid. Commoner access to economic resources such as land and food was strictly monitored, as was their ability to socially ascend. They primarily interacted with the lesser chiefs who administered the various communities for their overlords, although some commoners could obtain better chances of social advancement through military service. As armed conflict became more prevalent in the late seventeenth century, with greater numbers of commoners presumably being conscripted, this 
avenue of social advancement was likely tightened by elites. Lesser chiefs could also achieve access to the privileges of higher chiefly status through heroic acts of bravery in combat and loyalty to the ruling chief. An equal risk also existed for losing one's privileged status and rights in a given polity (or one's life), through acts of wartime cowardice or political treachery. It appears that commoners were not appropriate captives for ritual sacrifice upon war temples, although accounts of large-scale slaughter during heated battle ("until the rivers ran red" is one Hawaiian aphorism) presumably involved more commoner victims than chiefs. The job of cleaning the battlefield and burying the majority of the dead also fell to the commoners.

The accumulation of the material rewards of warfare often enumerated in the records of state-level societies elsewhere on the globe do not loom large in the ethnohistoric accounts of Hawaiian conflict. Agricultural surplus in an economy dependent on tubers, not grains (and lacking ceramics), was not easily stored or transferred in any quantity, although pigs represent a transformation of this productive capacity (Kolb 1999). Most combatants and civilian supporters captured during battle were apparently released, rather than enslaved as a source of ready labor. The capture of war canoes, weapons, feathered capes, and carved war-god images was likely appreciated in anticipation of future combat but was of little value in feeding newly conquered peoples. Reallocation of land and rights to agricultural surplus as tribute was therefore the greatest material reward to warfare, although only obtainable to members of the chiefly class and a few commoners (Klieger 1995; Sahlins 1992). The pyramidal nature of Hawaiian political structure required a victor to subsume conquered territory into the existing network of land managers and lesser chiefs. This growth in political authority also increased the potential of internal power struggles as the high chief distanced himself from his lesser chiefs, a scenario Kamehameha I soon faced after unifying the archipelago for the first time (Kuykendall 1968).

\section{Contact-era Warfare}

By A.D. 1778, warfare was conducted by well-organized groups of combatants numbering up to perhaps 15,000 individuals - the 1795 war fleet of Hawai' $i$ island chief Kamehameha I, for example, being comprised of four divisions of 300 canoes each (Sahlins
1992:41). Some chiefs such as Kahekili of Maui maintained a small elite core of warriors, providing specialized training in boxing, wrestling, spear dodging, and pole-vaulting (Malo 1951), as well as handto-hand combat techniques termed lua or "the art of bone breaking" (Kamakau 1961:77). Conscripted commoners represented the bulk of combatants enlisted for various terms of service. They presumably returned to subsistence pursuits when not engaged in warfare. As previously mentioned, certain chiefs and even commoners were rewarded for their role in particular campaigns by receiving tribute rights to certain plots of conquered land. In one instance Kamehameha put himself and his warriors to work planting a food-crop after a devastating but successful conquest of Hānā on Maui (Fornander 1969:216-217).

In addition to large war canoes capable of seating up to 20 warriors, a range of weapons was available for hand-to-hand combat including stone canoe breakers, lashed trippers, hand-held and hafted clubs, and sling stones; wooden thrusting and throwing spears, daggers, truncheons, and clubs; shark-toothstudded clubs and knuckle dusters; rope strangling cords; and an assortment of the same weapons using swordfish bills, whale bone, and later, historically introduced materials such as metal. Weaponry is rarely found in archaeological contexts; most examples are part of ethnographic collections, gathered by museums during the late eighteenth and early nineteenth century (Buck 1964). This makes discussing their role in the evolution of warfare difficult. The most important advancement was the post-Contact introduction of metal weapons and gunpowder. Hawaiians readily adapted to muskets, cannons, knives, swords, sailing vessels, and even Euroamerican fortifications (Mills 1996), modifying both the use and symbolic meaning of this new technology in their attempt to inherit its sacred power (or mana). For example, two British sailors, John Young and Isaac Davis, and an American sailing vessel were captured and employed by Kamehameha I in 1790 during his struggle with rival chiefs (Kuykendall 1968). The successful use of Western technology resulted in the eventual rising of the two expatriates to positions of power and influence in the Hawaiian kingdom.

Warfare in Hawai'i was an event of considerable complexity and intensity, involving not only ritual combat to seek revenge for real or imagined offenses 
between competing chiefly lineages (' $\overline{\mathrm{I}}$ ' $\overline{1} 1963$ ), but also the conquest of land and the capture of elite sacrifices to appease the gods (Valeri 1985) - the latter fate ultimately befalling Captain Cook when his negotiations with Hawai' $i$ island chiefs for succor went sour (Obeyesekere 1992). What is clear from ethnographic accounts it that warfare intensified after 1650, when the war gods Küka'ilimoku and Kahewila came into prominence on the leeward and dryer islands of Hawai' $i$ and Maui respectively. The wetter, Windward Islands (Moloka'i, O'ahu and Kaua'i) continued to worship the older Hawaiian gods Kane and Kanaloa in various permutations (Valeri 1985).

\section{The Rituals of War}

The most important material manifestations of the ritualization of warfare were dozens of sacred war luakini temples, physical settings where rituals were performed for the consecration of wars of conquest and the sacrificial offering of elite captives. War temples were large sancta where the supreme mediator of the supernatural, the paramount chief, conducted a series of important religious ceremonies that served to transform a successful military campaign into renewed social cohesion (Valeri 1985). They were functionally different from the lower-echelon ancestral shrines and productivity temples utilized by lesser chiefs and family groups as repositories for ancestral remains, local shrines for sacrificial worship, and/or places of lower-echelon feasting (see Valeri [1985:172-183] for a discussion of these types). War temples, built and consecrated throughout the islands, were the backdrop for a political landscape that served to rally a paramount's forces for battle, maintain political consensus for an impending war, and assure the participation of subordinate chiefs.

Each war temple was built and consecrated to a war god and served as a sanctum for rituals of divination before undertaking a military conquest. A ceremonial platform constructed of dry-laid stones was usually built and then embellished with elaborate material accoutrements and ceremonial trappings, including special hardwoods used to manufacture temple houses and images (Haleole 1919:80, 82; 'T''î 1963:43; Kamakau 1964:97; Malo 1951:166), as well as other woods valued for their aromatic or spiritual properties (Kolb and Murakami 1994). A sequence of war ceremonies would then take place, focusing upon sacrificial offerings to the war god. These ceremonies culminated with an elaborate pig sacrifice that served to transform the war god (the 'aha ho'owilimo'o rite). Hundreds of pigs were offered and publicly consumed ('I' $\overline{1}$ 1963:35; Kamakau 1964:105; Malo 1951:172; Valeri 1985:234-339) - a feast that served as a symbolic metaphor for divine consumption and the endowment of divine strength to worshipers (Sahlins 1985; Valeri 1985:57-59).

A particularly illustrative example can be found in the rise of the Hawai' $i$ island polity of Kamehameha I to prominence over the entire archipelago by 1810 . In this case, the war temple of Pu'ukohola was constructed in 1792 and dedicated to Kamehameha's personal god Kūka'ilimoku with the specific intent of sacrificing his uncle Keuōa, who also claimed the right to paramount power on the island. A specialized architect-geomancer (called the kahuna kuhikuhipu'one) determined the most appropriate ground plan and location for success and oriented the oracle tower to face southward in the direction of his uncle's residence in Ka' $\bar{u}$ (Valeri 1985:255). Although Keuōa apparently expected such a welcome, he still voyaged to see his nephew and was promptly sacrificed upon this brand-new war temple. Kamehameha then set off to conquer his archrival Kahekili of Maui. After ravaging Maui and then putting down a rebellion at home, he eventually defeated a combined invasion fleet put together by Kahekili and his brother Ka'eokū, paramount chief of Kaua'i. Shortly thereafter, the defiant but aged Kahekili died, leaving a power vacuum that resulted in a bloody struggle for rulership. Kamehameha relentlessly continued his assault, eventually annexing Maui, Moloka'i, and O'ahu. As conqueror he then sacrificed Kahekili's son Kalanikūpule on O'ahu in 1795, and shortly thereafter he rededicated all major Hawaiian temples to his war god Küka'ilimoku (Kamakau 1961:188). This was a deed that ritually solidified his ascension to the kingship of a multi-island kingdom.

\section{Places of Refuge and Retribution}

The concept of asylum and conflict avoidance was also important to Hawaiian society and worked in tandem with the concept of warfare. Physical locations of sanctuary, called places of refuge, were used as places of absolution for religious and political transgressors. As well as being agents of war; chiefs 
were also known as dispensers of peace and forgiveness, a Polynesian practice most highly developed in those island groups with the greatest hierarchical social structure (Kelly 1986a) such as Tonga (Gifford 1929), New Zealand (Best 1924), Tahiti (Henry 1928), and Sāmoa (Turner 1861).

In Hawai' $i$, places of refuge were often locales such as chiefly birthing places, chiefly residences, and chiefly burial places (Schoenfelder 1992). Often entire areas or communities could function as places of refuge, and even individuals such as paramount chiefs or their lands (called 'aina pu'uhonua) were considered a place of refuge (Kamakau 1961: 312-313). Most places of refuge were relatively modest in size, while others such as that of Hōnaunau on the island of Hawai' $i$ were walled complexes that included elite mausoleums and major temples where law breakers could retreat for absolution of their transgressions during times of peace (Barrere 1986; Schoenfelder 1992). Not surprisingly, these sanctuaries were also resorted to in times of war (Ellis 1917), and their recognized sanctity during conflict is corroborated by a complete dearth of ethnohistoric comment on their violation. Upon conquest of new lands, paramount rulers also had the authority to declare new places of refuge while abolishing old ones, a right exercised by Kamehameha I who, after his successful invasion of O'ahu in 1795, declared all lands of his wife Ka'ahumanu and those sacred to his war god Kūka'ilimoku as places of refuge. Interestingly, vanquished chiefs were not immune from retribution after military defeat. Oral traditions often mention the sacrifice of elite leaders and the purging/replacement of their subordinate hierarchy.

\section{Archaeological Evidence of Warfare}

The archaeological manifestations of warfare in Hawai'i during the precontact period have not been a major focus of attention due in part to a lack of direct material evidence (Earle 1997:134; Kirch 1990a). As previously mentioned, both skeletal evidence of violent trauma and material items such as weapons are somewhat lacking. Archaeological evidence of wartime injuries and ossuaries is also not widely reported when encountered, due to the cultural sensitivity of Hawaiian skeletal remains. However, recent archaeological investigations have shown that interpolity conflict is visible upon the landscape in subtle variations in temple construction (Kolb 1991, 1992, 1994; Kolb and Radewagen 1997) and in community and regional settlement patterns (Dixon et al. 1995). We will now examine these data more thoroughly.

\section{War Temples and Places of Refuge}

The most striking evidence for ancient warfare upon the Hawaiian archaeological landscape is the remains of temples used for consecrating wars of conquest and for offering sacrificial elite captives (Figure 1). What we know about temple function and chronology comes primarily from Maui (Kolb 1992, 1994, 1999; Kolb and Murakami 1994; Kolb and Radewagen 1997). The earliest Hawaiian temples, dating to ca. A.D. 1000-1200, are very small and have little or no sacrificial debris. This evidence represents the antecedent practice of public ancestor worship common throughout Polynesia. By ca. 1650, temples styles had branched into two distinct types: a number of large architecturally complex platforms with high quantities of sacrificial debris, and a multitude of smaller enclosure-style temples with little or no sacrificial debris. This rise in sacrificial activity represents a significant shift from the conceptual toward the economic, as temples began to be used for competitive status expression and chiefly aggrandizement.

Archaeological excavations of three historically documented war temples from Maui confirm that such temples possess the highest degree of architectural sophistication and ostentatious displays of material wealth that only the paramount chief could afford to build or accumulate, by virtue of his unquestioned authority over all means of production. These temples were embellished with elaborate material accoutrements and ceremonial trappings, including the remains of ceremonial feasting (Kolb 1999), special hardwoods used by artisans to manufacture temple houses and images atop a war temple (Kolb and Murakami 1994), and impressive architectural walls and trappings (Kolb 1992) that help imbue these special sancta with cultural connotations worthy of influential war rituals. The chronology of war temple construction and their function corroborate ethnohistoric evidence that suggests these ostentatious war rituals developed after A.D. 1650. Both ethnohistoric and archaeological evidence also suggest such temples were often remodeled and rededicated to different gods depending upon the whims of political rule. For example, each of three Maui war temples have earlier building episodes not associated with 


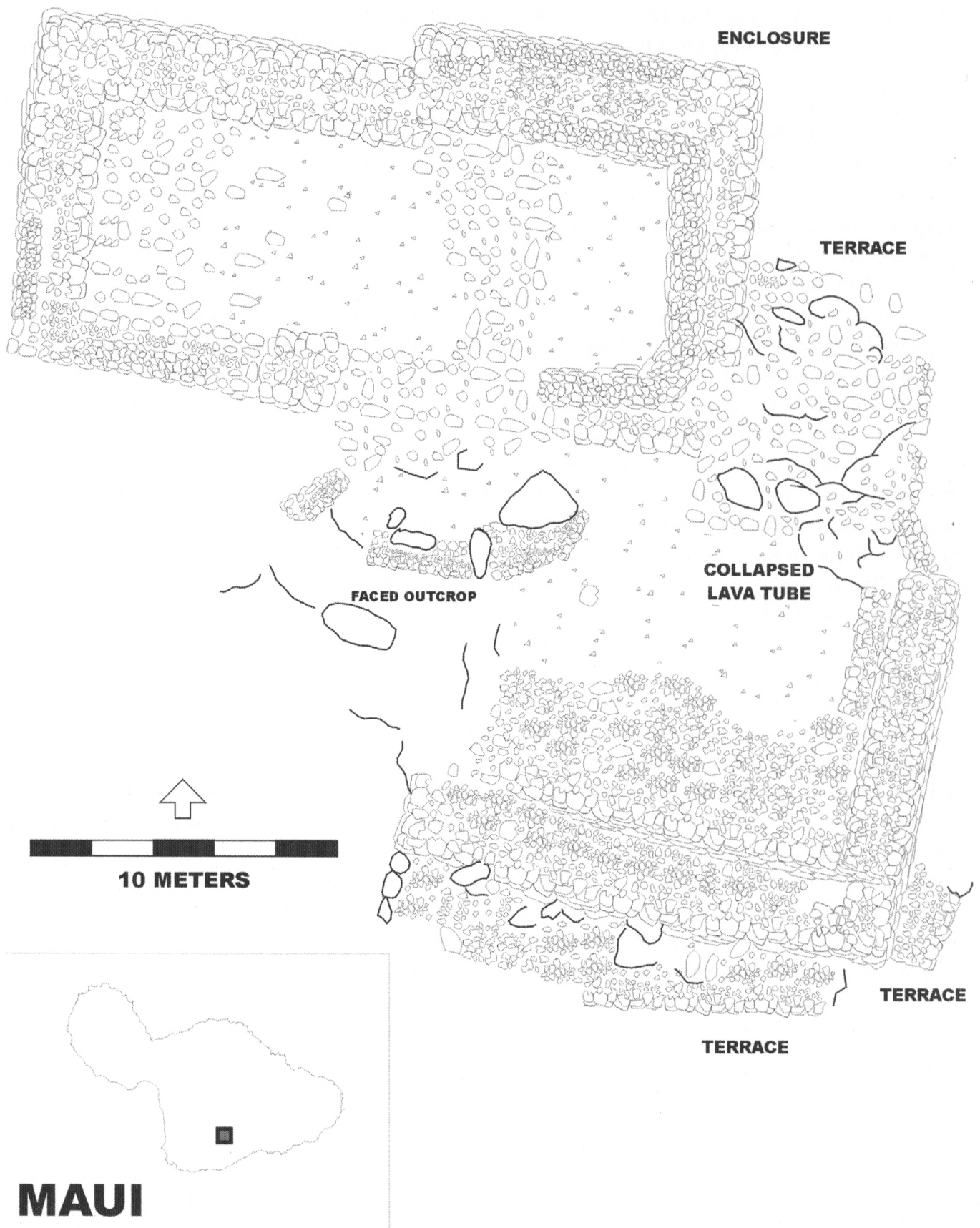

Figure 1. The remains of the war temple of Kohuluapapa Heiau, Kahikinui District, Maui (after Kolb and Radewagen 1997).

war at all, episodes that served as chiefly residences or ancestral shrines (Kolb 1999). By the eighteenth century, however, war temples became the focus of the most intensive sacrificial activities associated with transforming a successful interpolity military campaign into a renewed form of social cohesion, events that included initiation rites, sacrifices to ensure victory, and the sacrifice of elite captives to give thanks for victory. In real political terms, however, sacrificing one's rival made conquest easier.

Archaeological excavations at places of refuge include Hōnaunau on Hawai'i (Ladd 1969, 1985, 


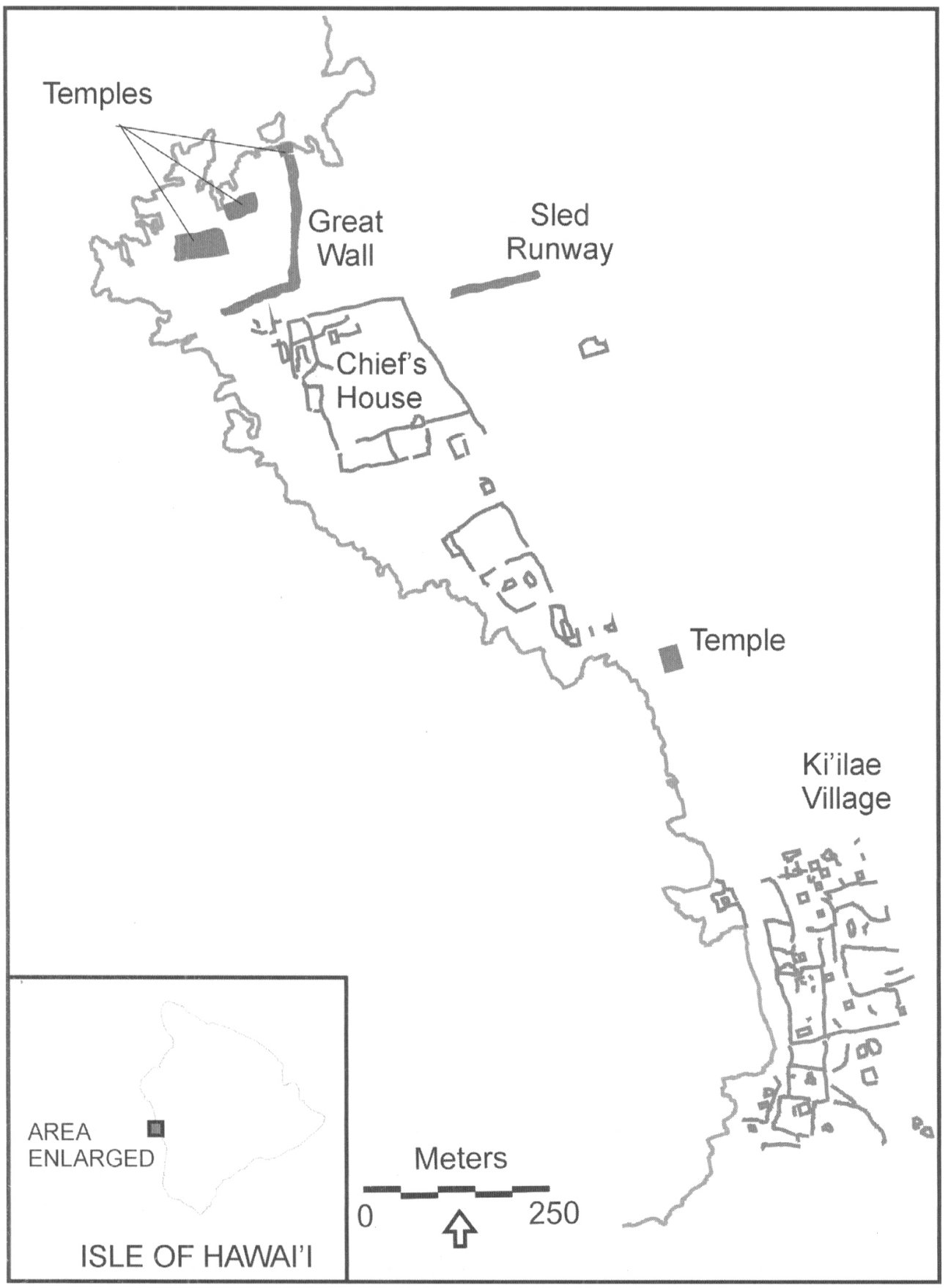

Figure 2. Place of refuge at Hōnaunau on the island of Hawai'i in context with its neighboring sites (after Ladd 1985). The great wall demarks the refuge itself.

1986, 1987) and Kukui o Puka and Popoiwi on Maui (Kolb 1991), and have revealed distinct places of ritual isolation, usually demarcated by an enclosing wall (Figure 2), perhaps serving to ritually and spatially enclose and protect refuge seekers while they waited for absolution. At both Hōnaunau and Popoiwi, associated temples and chiefly residential areas surrounded this ritual enclosure. Architecturally, it appears these refuge sites predate the war temples. Archaeological excavations also indicate 
Table 1. List of War Temples Collected from Early Hawaiian sources.

\begin{tabular}{|c|c|}
\hline Political District & War Temple (Site Number or Location) \\
\hline \multicolumn{2}{|l|}{ Hawai'i Island } \\
\hline Kona & Lono'akai (BM 50-Ha-D24-1), Palihiolo (HA 3842), Pakika (HA 3831), Ku'emanu (HA 3816), \\
\hline 'Ohi'amukumuku & (BM 50-Ha-D4-1), Ke'eku (HA 3818), Hopupalali (Ka'awaloa), Kamaiko (HA 3725) \\
\hline Ka'ù & $\begin{array}{l}\text { Halepohaha (HA 3658), Amamalua (HA 3611), Papamoana (HA 3593), Kamali’i (HA 3583), } \\
\text { Kohaikalani (HA 3538) }\end{array}$ \\
\hline Puna & Waha'ula (BM HV-276), Kue (BM 50-Ha-A17-2), Mahina'aka'aka (HA 2517) \\
\hline Hilo & Kanoa (BM 50-Ha-H20-1), Ohele (BM 50-Ha-H22-1) \\
\hline Hāmākua & $\begin{array}{l}\text { Manini (BM 50-Ha-G20-1), Honua'ula (HA 2117), Kaihalulu (BM 50-Ha-G11-1), Kalelemauli } \\
\text { (BM 50-Ha-G9-1), Ka'ape'ape (HA 2100), Haleiwa (BM 50-Ha-G3-3) }\end{array}$ \\
\hline Kohala & Pu'ukohola (HA 4139), Mo'okini (HA 2328), Mahikihia (Puako), Kauhuhu (Puako), Kapo (Puako) \\
\hline \multicolumn{2}{|r|}{ 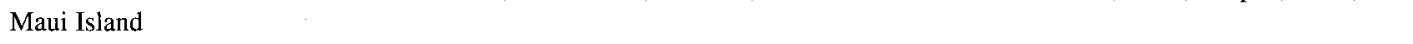 } \\
\hline Lahaina & Wailehua (MA 50-03-6), Halekumukalani (MA 50-03-7), Halulukoakoa (MA 50-03-11) \\
\hline Kä'anapali & Ma'iu (MA 50-01-20) \\
\hline Wailuku & Ulukua (MA 50-04-28), Kaluli (MA 50-04-42), Pihana (MA 50-04-44), \\
\hline Hāmākualoa & Po'oho'olewa (MA 50-06-68), Pu'uokaupu (MA 50-06-69), Pu'uokalepa (MA 50-06-72), \\
\hline Ko'olau & Pakanaloa (MA 50-07-84), Kalua nui (MA 50-07-95), Kukui'aupuni (MA 50-07-96), \\
\hline Hānā & Honuaula (MA 50-13-111), Kanawalu (MA 50-13-112), Kilinui (MA 50-13-114), \\
\hline Kiaplulu & Napa (MA 50-17-133), Maulili (MA 50-17-138) \\
\hline Kaupō & Loaloa (MA 50-16-101), Pu'umaka'a (MA 50-16-144), Halekau (MA 50-16-161) \\
\hline Kaihiknui & Kahikinui 3 (MA 50-15-181), Kohuluapapa (MA 50-15-186) \\
\hline Honua'ula & Kalani (MA 50-14-196), Pueo (MA 50-14-1020-200) \\
\hline Kula & Wailuku (MA 50-14-1031-205), Kolea (MA 50-14-1032-206), Mo'omuku (MA 50-11-224) \\
\hline \multicolumn{2}{|l|}{ Lāna'i Island } \\
\hline Lāna'i & Kahe'a (LA 294) \\
\hline \multicolumn{2}{|l|}{ Moloka'i Island } \\
\hline Kona & $\begin{array}{l}\text { Kalalua (MO 67), Pu'upapai (MO 123), Kamalae (MO 130), Mahinahina (MO 131), } \\
\text { Kaluakapi'ioho (MO 175), Paku'i (MO 178), 'Ili'iliopae (MO 200) }\end{array}$ \\
\hline Ko'olau & Pu'upa (MO 245), Ki'i /Pohakuloa (MO 246), Lalohana (MO 247), Hali’i (MO 251),Kapana (MO 252) \\
\hline \multicolumn{2}{|l|}{ Oah'u Island } \\
\hline Kona & $\begin{array}{l}\text { Papaenaena (OA 58), Hipawai (OA 63), Wakaina (OA 77-a), Maumae (Palolo), } \\
\text { Kanela'au (Pauoa), Halewa (Pauoa), Kawaluna (Nu'uanu) }\end{array}$ \\
\hline Ewa & Waikahi (OA 105), Hapupu (OA 129) \\
\hline Waianae & Nioiula (OA 149), Pu'upahe'ehe'e (OA 152), Kane (OA 160), Kamaile (OA 161), Ka'ahihi (OA 180) \\
\hline Waialua & Kalakiki (OA 197), Onehana (Waialua), Anahulu (OA 231) \\
\hline Ko'olauloa & Pu'uomahuka (OA 249), Nioi (OA 281) \\
\hline \multicolumn{2}{|l|}{ Kaua'i Island } \\
\hline Kona & Puuohewa (KA 23), Kuwiliwili (KA 48), Kukuiolono (KA 66), Weliweli (KA 83) \\
\hline Puna & Kalauokamanu (KA 102), Holoholoku (KA 106), Kawelomamaia (KA 112) \\
\hline Ko'olau & Kapinao (KA 129) \\
\hline Hanalei & Kalahihi (KA 134), Kaihalulu (KA 136), Po'oku (KA 139) \\
\hline
\end{tabular}

Note: Data from Emory (1924); Bennett (1931); Kelly (1986b); Kolb (1991); Sterling and Summers (1978); Stokes (1991); Summers (1971).

that both Maui refuge enclosures date to the $1400 \mathrm{~s}$ (Kolb 1994) and contain little or no evidence of human activity within the large enclosure except for bonfires.

Tables 1 and 2 list all war temples and places of refuge known ethnographically in Hawai'i. This list was compiled from ethnohistoric records, early archaeological research, and recent syntheses (Bennett 1931; Emory 1924; Kelly 1986b, Kolb 1991; Schoenfelder 1992; Sterling and Summers 1978; Stokes 1991; Summers 1971). Figures $3 a$ and $3 b$ are the respective geographic distributions for these sites, presented with the locations of all the major political and population centers. The number of both war temples and places of refuge present in each district varies considerably. These disproportionate distributions may be biased because many temples have since been destroyed by commercial agriculture or urban expansion. They may also be biased due to erroneous functional classification by early archaeologists or their local informants. Much of this documentation occurred at the turn of the twentieth 
Table 2. List of Places of Refuge Collected from Early Hawaiian Sources.

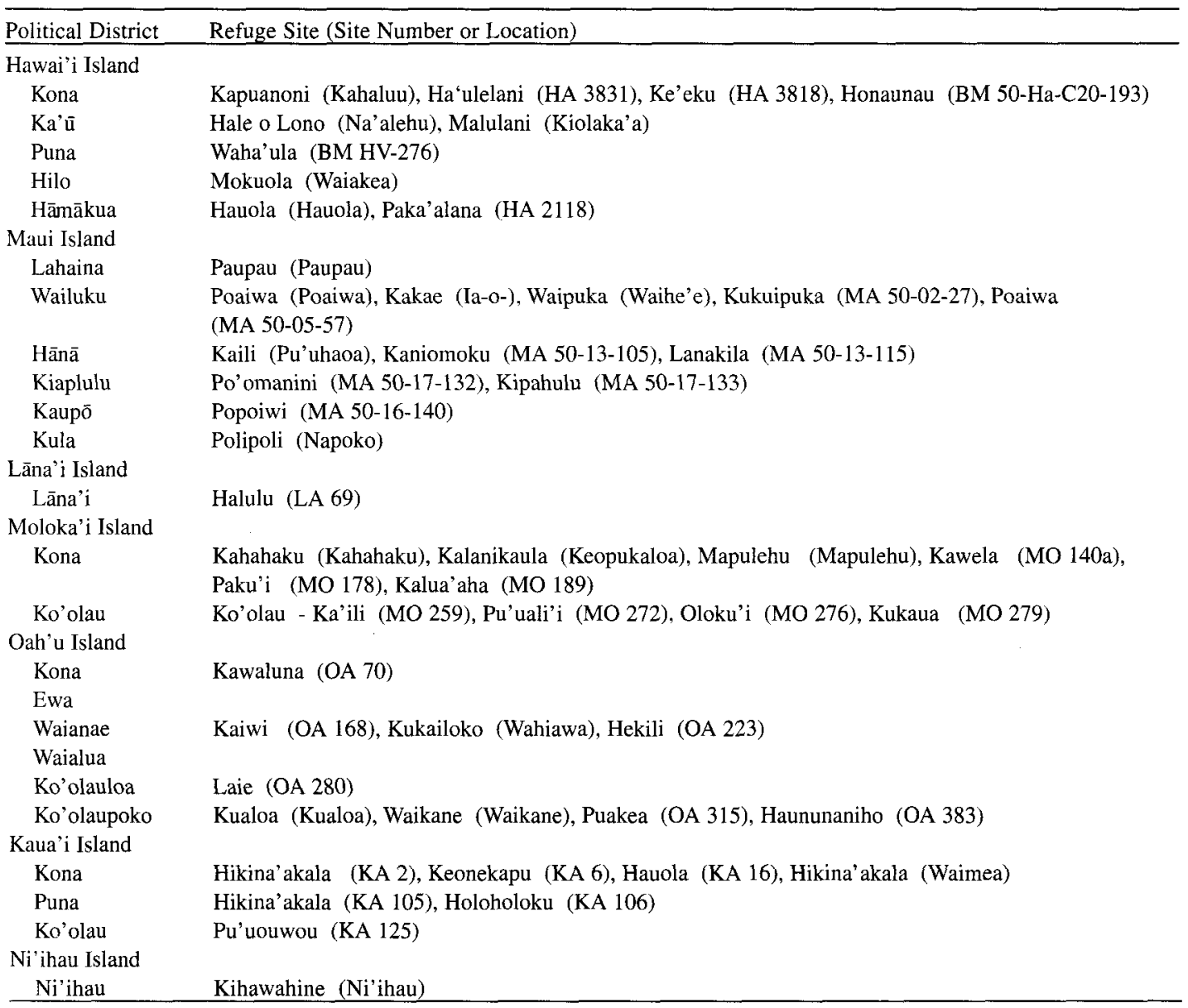

Note: Data from Emory (1924); Bennett (1931); Kelly (1986b); Kolb (1991); Sterling and Summers (1978); Stokes (1991); Summers (1971).

century, almost 90 years after the collapse of the Hawaiian kapu system. However, we argue that these data at least represent a more accurate picture than we could perhaps reconstruct today, since many of these sites no longer exist. Those that still do have at least been reexamined more thoroughly, or as in the case of the Maui temples, been exhaustively researched.

The distribution of known war temples and places of refuge reveals important clues regarding their societal importance. Hawai' $i$ and Maui islands have the largest number of temples ( $n=29$ and $n=28$ respectively), followed by O'ahu ( $n=18)$, Molokai'i $(n=$ $12)$, Kaua'i $(n=11)$, and Lāna'i $(n=1)$. War temples are fairly evenly distributed around the islands ( 29 out of 23 political districts, or 88 percent) and seem to confirm ethnohistoric records (Malo 1951:159-189; 'I''i 1963:137, 160; Kamakau 1976:129-131) that mention that each political district did indeed have its own war temple. Many of the districts, including major political and population centers, had more than one temple. Figure $3 \mathrm{~b}$ shows the distribution of 49 places of refuge. Maui ( $n=13$ ) has the largest number, followed by Hawai' $i$ and Moloka'i ( $n=10$ each), Oa'hu $(n=9)$, and Kaua'i $(n=7)$. Lāna'i and Ni'ihau islands have one refuge each. There are fewer than half as many of refuges as war temples, distributed in only 23 out of 33 political districts ( 70 percent). Despite a misleading ethnohistoric source that indicates at least one place of refuge was found in every political district (see Schoenfelder 1992:35-36), Figure 3a shows 


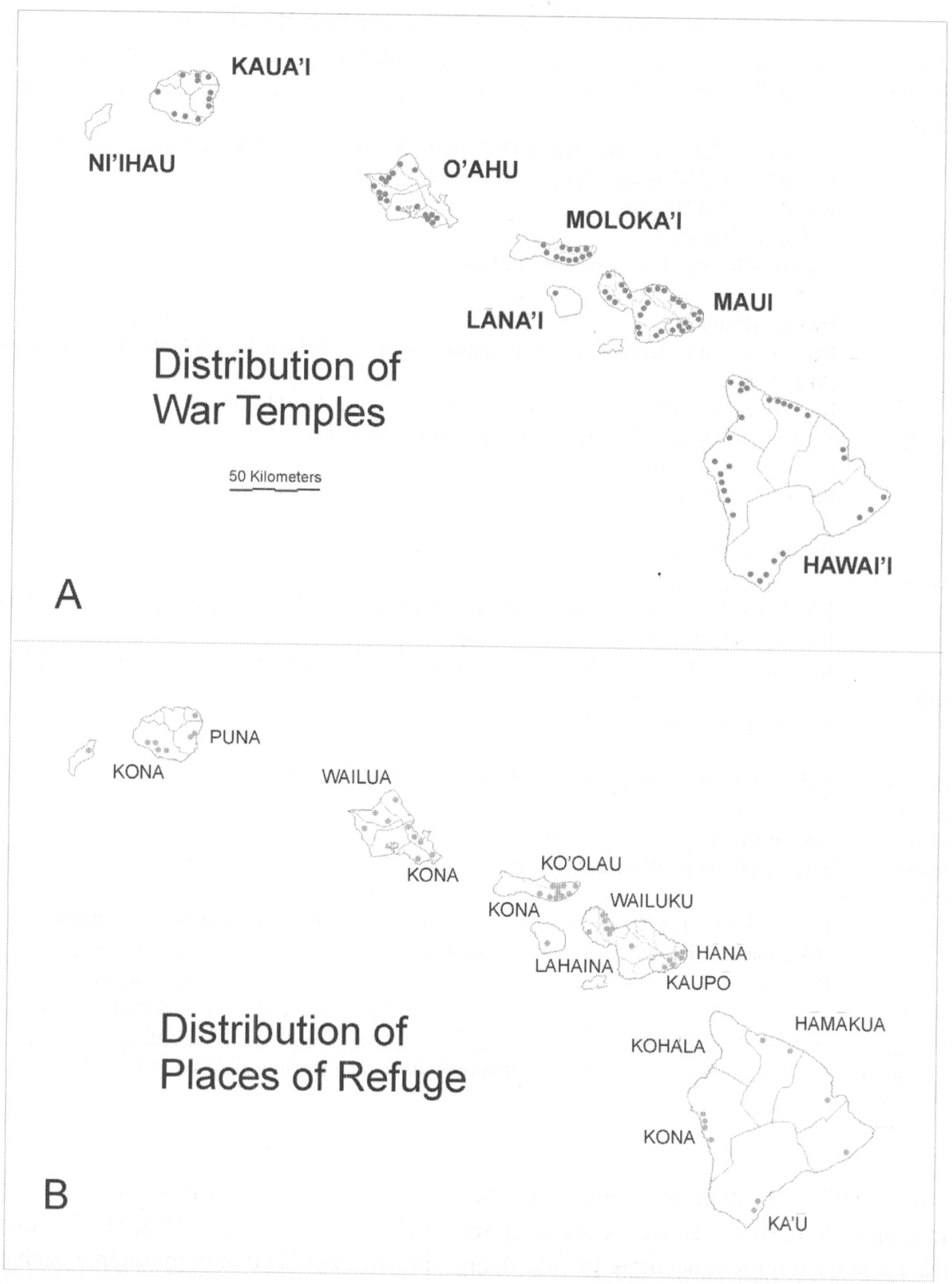

Figure 3. The respective geographic distributions of major political and population centers and all war temples (3a) and places of refuge (3b) known ethnographically on the islands of the Hawaiian archipelago.

that this is clearly not the case. Ten political districts lack even a single refuge site, while major centers seem to have as many as five refuges. Nearest-neighbor analysis of war temples reveals a near random distribution $(R=1.05, n=99)$, while the distribution for refuges is only slightly more uniform $(R=1.13$, $n=49)$.

Overall, Maui has the highest total of warfarerelated sites $(n=42)$, followed by Hawai' $\mathrm{i}(n=39)$, O'ahu ( $n=27)$, Moloka'i $(n=22)$, Kaua'i $(n=18)$,
Lāna'i $(n=2)$, and Ni'ihau $(n=1)$. The denser concentration of war sites on the leeward and dryer islands of Maui and Hawai'i coincides with ethnographic accounts such as zones of worship of the war gods Kahewila and Kūka'ilimoku, loci of the earliest and most sustained conflicts, and islands with unstable dryland productive economies (Hommon 1986:67; Kirch 1990b:336).

Figure 4 shows the distribution of war-related site types on Maui. War temples are somewhat uniform 


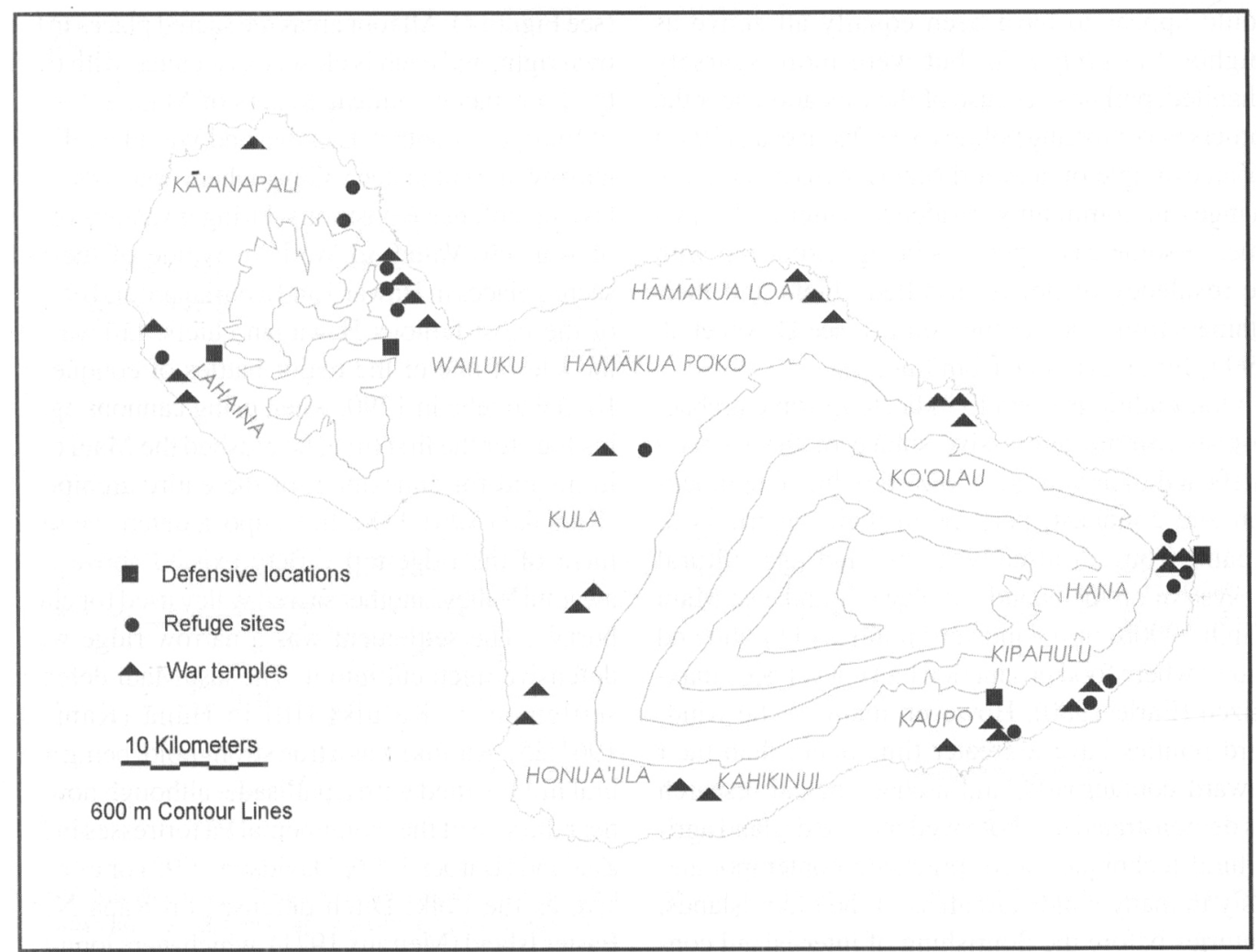

Figure 4. The archaeological landscape of the island of Maui, with names of each political unit.

in their distribution among political districts (nearest-neighbor $R=1.23, n=28$ ). In contrast, the distribution of refuge sites is restricted to six districts and appears a bit more regular $(R=1.40, n=13)$. In west Maui, these refuges are located in the two major political centers, Wailuku and Lahaina. A single refuge is found at the hilltop of Polipoli in Kula district. The east Maui refuges are located primarily in Hānā and its neighbors Kīpahulu and Kaupō. Hānā is the major political district of east Maui and the ruling center of the traditional rivals of the west Maui chiefs. A number of districts apparently lack places of refuge, a pattern also seen on the other islands, at least as far as we can ascertain from the literature. Whether places of refuge were introduced by $\mathrm{Pa}$ 'ao in the thirteenth century A.D., or adopted by Hawaiians later as a response to the development of severe royal laws and the cult of human sacrifice, is not known. It would appear, however, that places of refuge became an integral part of the practice of warfare and provided a very real "release valve" for the pressures inherent in interpolity conflict. The existence of places of refuge also hints at possible perceptions of warfare by the Hawaiian population as part of a ritually defined exercise that had recognized bounds of propriety, regardless of its severity.

A number of temporal trends also exist in regard to political and military conflict. Prior to 1650 , we have evidence of two distinctive regional temple styles on Maui. East Maui, a politically autonomous polity prior to island unification (Kolb 1994), has terraced-style temples, while rival west Maui had enclosure-style temples. This was a time when both east and west Maui were powerful polities whose relationship was one of rivalry and conflict (Cordy 1981; Hommon 1976, 1986; Kolb 1991). After 1650, when the west Maui chiefs eventually annexed east Maui, east Maui temple style shifts to enclosures.

\section{Settlement Trends and the Rise of Defensive Locations}

Another temporal trend that may be associated with warfare is the series of intermediate or buffer zones present between conflicting areas. Many of these zones, as detected by the absence of archaeological sites, were marginal lands for agriculture and were unoccupied prior to 1650 (see Cordy [2000] for examples on leeward Hawai' $i$ island). Other areas 
would appear to have been equally attractive as neighboring ahириа'a, but were more sparsely inhabited, perhaps because of their location near the borders of competing polities (see Dixon et al. [1997] for an example on leeward Maui). Also evident are changes in community residence patterns through time, in some cases perhaps being associated with the residency of newly installed chiefs and their retainers from conquering polities (see Dixon et al. [1995] for an example from Lāna'i).

Oral traditions seem to indicate to some archaeologists a more aggressive stance of the leeward chiefs and their war gods toward political competition and conquest, perhaps in their eagerness to expand from an already intensified agricultural ecosystem on the islands of Hawai' $i$ and east Maui (Kirch 1990b) into windward polities of O'ahu and Kaua' $i$ where food production had not yet been maximized (Earle 1980). However, many of the windward polities have a greater time depth than their leeward counterparts, and archaeological research has demonstrated that both wetland and dryland agricultural techniques were practiced contemporaneously in many windward areas of the older islands, centuries before the flourishing of inter-island conflict. Moreover, recent settlement pattern studies in upland east Maui (Dixon et al. 1997; Kolb et al. 1997) suggest that the potential carrying capacity of some leeward lands had yet to be fully realized by late pre-Contact and early post-Contact populations periodically engaged in interpolity warfare.

We have already noted the rise of the war temple and sacrificial activity after 1650 , but we also note another important trend in Hawaiian warfare during this time: the development of defensive locations. It is interesting to note that despite archipelago-wide endemic warfare and the increasing scale of the opposing forces, little evidence of major labor investment in fortifications or permanent defensive settlement locations is found-something that differentiates the Hawaiian case from other ancient societies engaged in interpolity warfare. During times of war, places of refuge and fortresses were sometimes constructed, but only "by the common 'Polynesian method of isolating an area by cutting trenches across narrow access routes" (Tuggle and Tomonari-Tuggle 1980:311-312); a well-preserved example may be found at Ho' okio Ridge on Lāna'i (Emory 1924).

On Maui, evidence for four defensive areas exists (see Figure 4). All four areas are sacred places in their own right, and each is closely associated with one of the four major political centers of Maui at the time of European contact. Lahaina and Wailuku relied on narrow amphitheater valleys where warriors would take up defensive positions during invasions or time of war. Iāo Valley in Wailuku is one of the most sacred places in Hawai' $i$ and a burial ground of many of the most famous Hawaiian chiefs. Iâ̄o was also the site of one of the major battles of conquest by Kamehameha in 1790, when using cannons against his foes for the first time, he crushed the Maui chiefs in his bid for annexation of the entire archipelago (Kamakau 1961:148). In Kaupō, a defensive settlement of the ridge-top variety existed above Manawainui Valley, another sacred valley used for chiefly burials. The settlement was a narrow ridge with a defensive ditch cut into it. The last Maui defensive settlement is Ka'uiki Hill in Hānā (Kamakau 1961:25). Ka'uiki was a true stronghold, being a natural hill fortified with a pallisade, although nowhere near the size of the monumental Pă fortresses in New Zealand (Barber 1996; Davidson 1992) or as extensive as the Poiki Ditch defenses on Rapa Nui or Easter Island (Metraux 1971), which were long-term settlements in their own right. Ka'uiki was located at the strategic Hānā Bay and had a war temple located in its shadow. Ka'uiki was the site of some of the most protracted sieges that occurred during the conflicts between the Hawaiian island chiefs and their Maui rivals.

On the island of Hawai' $i$, where Kamehameha I and his war god Kūka'ilimoku ruled, a very different adaptation to warfare developed. This adaptation was referred to somewhat derogatorily in the Hawaiian language as pe'e pao or "hiding in a cave" (Pukui and Elbert 1971:297). Such a response is similar to other Polynesian islands where endemic warfare took its toll on the local populace, such as Rapa Nui (McCoy 1976), Mangareva (Laval 1938), Tonga (Collocott 1919), Reef Island (O'Farrall 1904), and Sāmoa (Nelson 1925). On both windward (Major et al. 1992) and leeward (Schilt 1984) sides of Hawai'i island, natural lava tubes were modified with thick walls and narrow crawlways for easy defense (Figure 5). The entrances to these caves were often disguised to avoid being discovered by marauding warriors, and weapons were sometimes cached near the doorways for use in defense. While variation in architectural modifications to these lava tube 


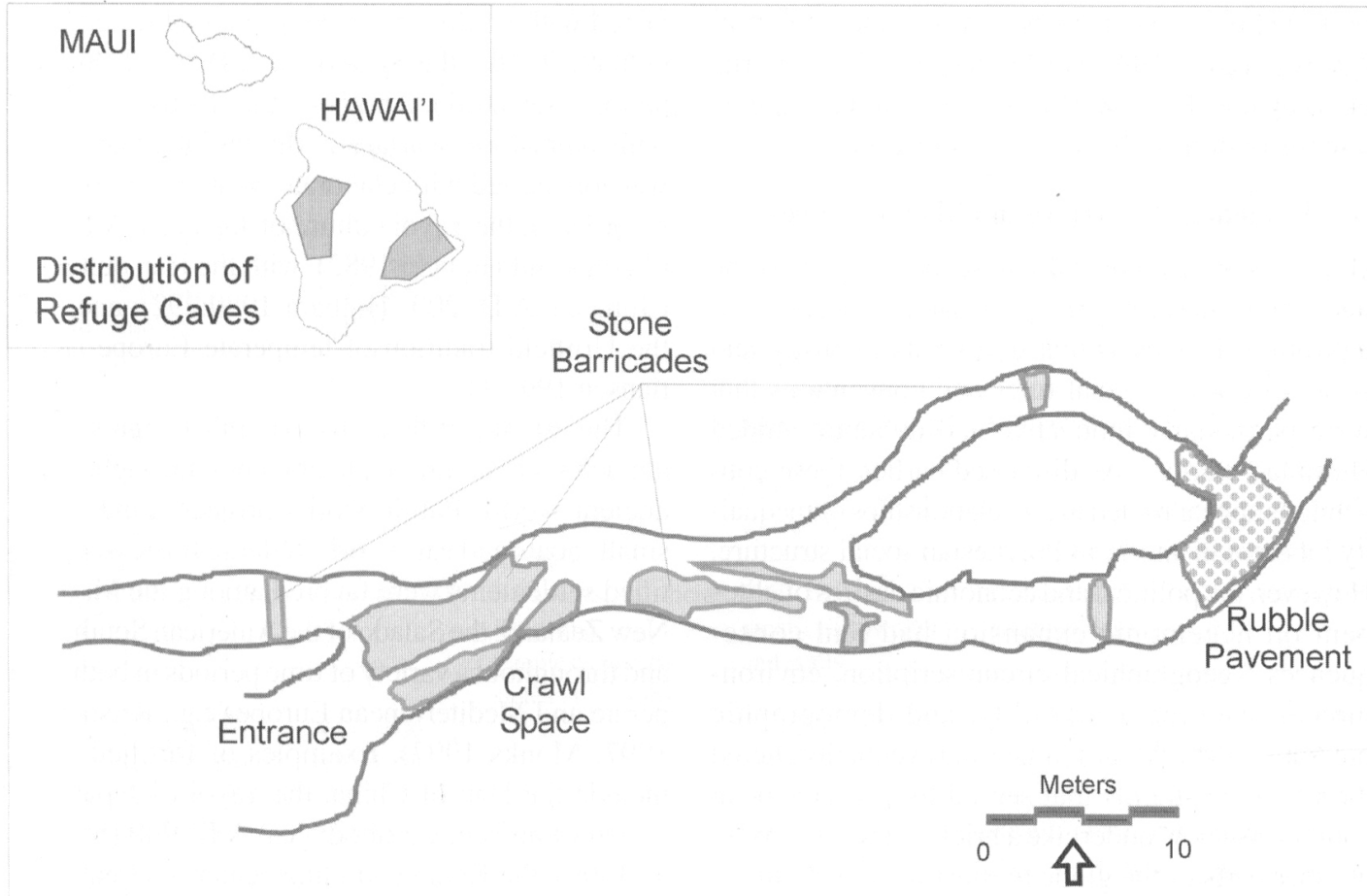

Figure 5. Site 50-10-44a-5060 from the island of Hawai'i. Site 5060 is a lava tube cave modified with thick walls and narrow crawlways for easy defense (after Kennedy and Brady 1997).

entrances suggests a strong correlation with social status to some archaeologists (Kennedy and Brady 1997), the residential environment within the lava tubes is very similar to that found in most traditional communities outside; these remains include paved trails, cooking areas, sleeping and burial platforms, animal enclosures, and storage features. A multitude of fire hearths, midden debris, and hand tools also suggests that inhabitants carried out many of their normal daily activities underground, although the low density of refuse generally indicates that most of these refuge caves were not inhabited for any appreciable length of time.

Not surprisingly, in the district of Kona on the leeward side of Hawai'i Island there appears to be a strong correlation between the loci of battles fought after 1782 between Kamehameha, his cousin Keōua, and rival chief Kalaniopu'u's son Kiwalo, and the locations of many known fortified lava tubes (Kennedy and Brady 1997). During this same time period, the earlier occasional use of isolated lava tubes well above permanent coastal settlements seems to have been supplemented by the establishment of additional settlements near fortified tube entrances and agricultural fields (Kennedy and Brady
1997). Such a defensive posture suggests that crop burning and slaughter of defenseless civilians (Kamakau 1961:235) only became a permanent threat relatively late in the history of armed conflict. Lava tubes as a geological phenomenon are more widely distributed in areas of relatively recent vulcanism (Hawai' i Island and eastern Maui). The general lack of refuge cave elaboration on Maui suggests that resource availability alone did not determine the defensive strategies selected by combatants and their resident populations. Perhaps the restricted development of refuge cave sites to the island of Hawai' $i$ (see Figure 5) may be due to the increasing ferocity of conflicts in certain areas, for unlike the defensive sites of Maui, these lava tubes were used primarily by noncombatants. Perhaps the intrapolity fighting associated with Kamehameha's political ascendancy was more fierce than oral history reveals; a lack of descriptive details of these battles may be due to the fact that Kamehameha was the eventual victor, and details would perhaps have been assuaged to bolster his new role as unifier. Moreover, the lack of internecine feuding among the remaining islands (including Maui) at this time might be due to the unified and more stable multi-island polity controlled 
by Kahekili. It may have been that Kahekili's strategy was more defensive, protecting his territorial gains against his powerful rival by forcing siege on a series of defendable Maui fortifications.

\section{Evidence of Warfare in Other Cultures}

Hawai'i's archaeological landscape provides some interesting clues concerning the nature of warfare ritualization. It is clear that despite its intensity and scale, a series of social rules and conventions that were particularly innovative and dynamic guided Hawaiian warfare. As discussed earlier, these conventions appear rooted in the relationships of inequality inherent in ancestral Polynesian social structure. However, the political and economic desires of elites bent on hegemonic expansion had real consequences-geographical circumscription, environmental resource availability, and demographic pressure-factors that strained and eventually altered the ritual constraints that served to mediate social conflict. We now undertake a brief review of warfare in other parts of the globe to illustrate this point.

For our comparison, we have identified four general categories of archaeological evidence visible upon the landscape: ritual architecture, fortifications, defensive settlement patterns, and places of refuge. These categories are present in a number of other hegemonic polities that were at a similar level of sociopolitical complexity as Hawai'i at European contact (Table 3 ). Since intensive warfare may rarely leave obtrusive traces in preindustrial societies such as Hawai' $i$, we focus on archaeological examples that have already been interpreted as conflict-related. Although many of these comparative cases possess additional archaeological evidence (artifactual or skeletal) indicative of intensive conflict, our focus is to illustrate variations in the rules and conventions of combat.

First, it appears that the use of ritual architecture for the purpose of sanctifying warfare is not only a Polynesian trait. The sacrifice of wartime captives was a primary method of expressing the subjugation of conquered polities in the Late Classic Maya area circa A.D. 900 (Webster 1977, 1993). Such public rituals were often performed in sacrificial temples (Fash et al. 1992) and ballcourts (Fox 1996) replete with carved statuary extolling the virtues of warrior kings (Houston 1992, 1993; Johnston 1985; Schele and Miller 1986). In the North American Southwest, ceremonial plazas were likely the loci of rituals asso- ciated with conflict between groups of desert agriculturalists like the Salado ca. A.D. 1450 (Simons and Gosser 2001). Another ritual locus associated with prehistoric warfare is the burial ground, and warriors buried with elaborate weaponry have been recorded in the Yayoi culture of Japan ca. A.D. 200 (Aikens and Higuchi 1982), with the Han culture in China ca. A.D. 200 (Higham 1989:292), and with the Urnfield tradition of temperate Europe (Kristiansen 1997:111).

The use of fortifications to combat aggression is a much more common phenomenon throughout the ancient world. Public-works projects range from small moats and earthworks to large fortresses. Fortified settlements were favored among the Maori of New Zealand, the Salado of the American Southwest, and throughout a variety of time periods in both temperate and Mediterranean Europe (e.g., Kristiansen 1997; Monks 1997). Examples of fortified cities include the Han of China, the Yayoi of Japan, the Funan of ancient Cambodia ca. A.D. 900 (Stark et al. 1999), the Karanga trading center of Great Zimbabwe in Africa ca. A.D. 1500 (Connah 1987), the lowland Maya ca. A.D. 200 (Matheny 1986; Webster 1976), and the American Mississippi Valley ca. A.D. 1400 (Pauketat 1994:91-92). The Inca fortress of Sacsahuaman in Peru ca. A.D. 1400 represents an example of an even larger-scale public project (Haas et al. 1987), probably constructed with the labor of other conquered highland societies.

Intervisibility and hilltop defense are also important factors in the placement of settlements and villages (e.g., Monks 1997:13; Redmond 1994:36). Hilltops and ridges were the favored locations for fortified villages among the Maori of New Zealand, the Yayoi of Japan, the Karanga of Africa, Urnfield and Mediterranean Europe, and the Salado. In the lowland Maya area during the Early Classic Period ca. A.D. 400 , many centers were located near swamps and streams that could be easily defended by the construction of walls and palisades (Puleston and Callender 1967; Rice and Rice 1981). Similar techniques continued to be used into the end of the Classic Period ca.A.D. 900 in the Petexbatun lake district (Demarest et al. 1997). Centuries later during the Postclassic Period ca. A.D. 1200, the highland Maya (DeMontmollin 1989; Fox 1987) and their neighbors (Dixon 1987; Joyce 1991) built easily defended villages on tall hilltops overlooking their fields and the narrow access routes in and out of their valleys. The 
Table 3. Archaeological Landscape Characteristics of Selected Polities.

\begin{tabular}{|c|c|c|c|c|c|c|}
\hline Culture & Region & $\begin{array}{l}\text { Approximate } \\
\text { Time }\end{array}$ & Ritual Architecture & $\begin{array}{l}\text { Large-scale } \\
\text { Fortifications }\end{array}$ & $\begin{array}{l}\text { Defensive } \\
\text { Settlement Patterns }\end{array}$ & $\begin{array}{l}\text { Places of } \\
\text { Refuge }\end{array}$ \\
\hline Hawai'i & Polynesia & A.D. 1600 & War temples & Notched ridge-tops & $\begin{array}{l}\text { Dispersed } \\
\text { No visible } \\
\text { defenses }\end{array}$ & $\begin{array}{l}\text { Ritual } \\
\text { enclosures } \\
\text { Cave } \\
\text { sanctuaries }\end{array}$ \\
\hline Maori & Polynesia & A.D. 1600 & & $\mathrm{~Pa}$ - fortresses & Hilltop locations & \\
\hline Urnfield & Europe & 1000 B.C. & Warrior burials & Walls and towers & Hilltop settlements & \\
\hline Karanga & Africa & A.D. 1500 & & $\begin{array}{l}\text { Great Zimbabwe } \\
\text { Enclosures }\end{array}$ & Hilltop villages & \\
\hline Yayoi & Japan & A.D. 200 & $\begin{array}{l}\text { Warrior burial } \\
\text { mounds }\end{array}$ & Moats and palisades & Hilltop villages & \\
\hline Funan & Cambodia & A.D. 900 & & City walls and moats & & \\
\hline Han & China & A.D. 200 & $\begin{array}{l}\text { Warrior burial } \\
\text { mounds }\end{array}$ & City walls & & \\
\hline Maya & Central America & A.D. $400-900$ & $\begin{array}{l}\text { Ballcourts; sacrificial } \\
\text { altars and } \\
\text { temples; carved } \\
\text { stelea and tombs }\end{array}$ & $\begin{array}{l}\text { Early Classic } \\
\text { moats, earthworks, } \\
\text { and walls }\end{array}$ & $\begin{array}{l}\text { Lowland and } \\
\text { hilltop villages }\end{array}$ & Caves \\
\hline Inca & South America & A.D. 1400 & & Sacsahuaman fortress & Hilltop villages & \\
\hline Cahokia & North America & A.D. 1400 & & Pallisades & $\begin{array}{l}\text { Dispersed riverine } \\
\text { settlements }\end{array}$ & \\
\hline Salado & North America & A.D. 1450 & $\begin{array}{l}\text { Ceremonial } \\
\text { plazas }\end{array}$ & $\begin{array}{l}\text { Walls; } \\
\text { rooftop entrances }\end{array}$ & $\begin{array}{l}\text { Riverine promontories } \\
\text { Platform mound } \\
\text { villages }\end{array}$ & \\
\hline
\end{tabular}

Inca employed much the same tactic, with the highland town and ceremonial center of Machu Picchu typifying this settlement pattern. Also important to the Inca was the policy of relocating fractious lowland ethnic communities into more easily managed highland landscapes (D'Altroy 1994), pressing them into labor on local defenses at the same time.

Evidence is scarce for refuge places in other parts of the world. It is possible that some caves, such as Naj Tunich in the Maya area, served as neutral sanctuaries between warring polities (Brady et al. 1997; Stone 1995). Places of refuge in Hawai' $i$ were formally recognized locations or enclosed sites, providing sanctuary for a privileged few from the ravages of warfare and the perils of daily life within the kapu system. Short-term refuge by the general population on Hawai'i island used fortified and/or hidden lava tubes, a trait common in other places in Polynesia (Collocott 1919; Laval 1938; McCoy 1976; Nelson 1925; O'Farrall 1904). However, the sanctity of formal refuge during times of conflict, as typified in the Hawaiian places of refuge, does not seem to have been an essential element of warfare elsewhere outside of Polynesia.

In contrast to most places in the world, Hawaiian fortifications were minimal and most likely used for a short-term and desperate defense by a handful of already beleaguered warriors. Even compared to other parts of Polynesia such as New Zealand where labor-intensive $\mathrm{Pa}$ ring-compounds were common (e.g., Davidson 1992), the Hawaiian forts suggest a relatively minimal level of sustained conflict. Defensive settlement patterns in Hawai'i are not apparent in the archaeological landscape, suggesting that most coastal settlements predate the era of intense conflict, and their inhabitants were not particularly worried about interpolity violence. The dispersed nature of traditional Hawaiian settlement is especially evident in upland environments (Kirch 1985), suggesting that later inland settlements were not the systematic target of organized combat.

\section{Conclusions}

We have identified four general categories of architectural evidence related to the rules and conventions of warfare: ritual structures, fortifications, defensive settlement patterns, and places of refuge. These categories are present not only in Hawai' $i$ but in other parts of the world as well. Comparative analysis of the scale and distribution of these cate- 
gories is useful for clarifying variation in the rules and conventions of warfare. Our analysis illustrates how the ethics of warfare (Demarest 1978) in various societies may deviate upon the landscape despite common root causes (e.g., status rivalry, demographic pressure, circumscribed resources, accumulation of material wealth).

One of the most striking contrasts of Hawai' i to other world regions is the degree to which a series of prescribed social mechanisms were used to peacefully resolve or avoid armed combat. Dispersed Hawaiian settlement patterns, refuge caves, and places of refuge appear to signify an expected resolution to such conflict over a relatively short period of time, with the possibility of reprieve for combatants regardless of the intensity of warfare or the certainty of sacrifice. Moreover, Hawaiians were able to incorporate European armament into the traditional rules and expectations of combat, a phenomenon that directly led to archipelago consolidation under the reign of Kamehameha I. These same mechanisms appear to be absent (or at lease less visible) in other regions of the world, perhaps precluding many complex hegemonic polities from forging stronger interregional bonds over time.

Yet even the ritualized conventions of Hawaiian warfare became severely tested as the scale and political goals of combat intensified over time. Clearly these conventions changed to best suit the political and economic desires of the elite, or as a response to intensifying conflicts. The growing nature of human and animal sacrifice, the use of places of refuge in response to these ideals, and the late modification of lava tubes as temporary civilian refuges appear to represent scalar stress on these conventions. By A.D. 1800 conflict seems to have escalated to endemic proportions. Ritual conventions were somewhat ineffectual and in some ways (such as the desire to sacrifice large quantities of foodstuffs) helped promote territorial aggrandizement. Western contact accelerated this spiral toward political centralization by introducing modern weapons and thereby causing technological imbalance.

Another significant contrast is that, despite the ferocity and importance of warfare in Hawai' $i$, very few obtrusive traces exist in the archaeological record. Organized conflict seems to have been every bit as labor intensive, ritualized in conduct, and physically violent as prehistoric warfare in the Maya or Inca areas with the outcome being virtually the same for elite captives, and eventually, for noncombatants. If we read the ethnohistoric accounts correctly, these ethical distinctions probably did little to alter the intensity of behavior for Hawaiian warriors during actual combat. Yet a distinct discrepancy exists between ethnohistoric descriptions of warfare and what the archaeological record actually shows. Even in comparison with other culture areas of similar scale and population density, Hawai'i lacks categories of material evidence common to other places of the world. Perhaps, as in other areas of the world, this is because economic and environmental pressures (such as demographic saturation) had not yet peaked, pressures that had devastating effects on other Polynesian societies such as Rapa Nui and New Zealand.

This study of warfare was accomplished by using archaeological data that reveal different aspects of the landscape of warfare. When woven together with oral histories they tell a dramatic story of how the rules and conventions of conflict changed, and illustrate how innovative and dynamic Hawaiian warfare actually was. The similarities and differences observed between Hawaiian warfare and those from other regions of world should not easily be dismissed but must be compared and examined. While this example of the changing ideological role of warfare is tailored to the rise of a complex chiefdom in Hawai' $i$, we argue these data have broader significance for interpreting and illustrating how the social processes surrounding warfare may be interwoven with economic and environmental issues when discussing historical or archaeological change.

Acknowledgments. Financial support for the Maui temple research came from the National Science Foundation (BNS 9016645 and BNS 9708341), the University Research Expeditions Program, the Native Hawaiian Culture and Arts Program (NHCAP), California Friends of Archaeology, the Department of Anthropology of the University of California at Los Angeles, the University of Hawai'i Committee for the Preservation of Hawaiian Language, Art, and Culture, the Department of Hawaiian Home Lands, the Hawai'i State Parks Division, the Hawai'i Historic Preservation Division, and the late John C. Elliott.

The authors would like to thank several individuals for their patience in helping us explore some of the intricacies of prehistoric warfare in several culture areas. Special thanks go to David Webster for insightful comments and discussion. Steve Houston, Kevin Johnston, Patricia McAnany, and Terry Stocker also shared their knowledge and intuitions concerning the nature of Maya conflict. Steve Athens, Ross Cordy, Tom Dye, and Patrick Kirch discussed the subject within the 
Polynesian context. James Brady, Joseph Kennedy, and Maurice Major explored the realm of cave use and refuge in Polynesia with the authors, and Dennis Gosser shared his knowledge of the American Southwest. Last but not least, Robert Hommon, Winnifred Creamer, Jonathan Haas, and four anonymous reviewers provided valuable comments. Any misrepresentation of the data presented here or their interpretation is the sole responsibility of the authors.

\section{References Cited}

Aikens, C., and T. Higuchi

1982 Prehistory of Japan. Academic Press, New York.

Ashdown, I.

1979 Notes on Maui Cultural Remains. Maui Historical Society.

Athens, S., and J. Ward

1993 Environmental Change and Prehistoric Settlement in Hawai' i. Perspectives 32:205-223.

Barber, I. G.

1996 Loss, Change, and Monumental Landscaping: Towards A New Interpretation of the "Classic" Maori Emergence. Current Anthropology 37:868-880.

Barrere, D.

1986 A Reconstruction of the History and Function of the $P u$ 'uhonua and the Hale O Keawe at Honaunau. In The Natural and Cultural History of Hōnaunau, Kona, Hawai'i. Departmental Report Series 86.2 , edited by E. Bryan and K. Emory, pp. 117-136. Department of Anthropology, Bishop Museum, Honolulu.

Bennett, W.

1931 Archaeology of Kauai. Bishop Museum Bulletin No. 80, Bishop Museum Press, Honolulu.

Best, E.

1924 The Maori, vols. 1 and 2, Memoirs of the Polynesian Society Vol. 5. Board of Maori Ethnological Research, Wellington.

Brady, J., A. Scott, A. Cobb, I. Rodas, J. Fogarty, and M. Sanchez

1997 Glimpses of the Dark Side of the Petexbatun Project: The Petexbatun Regional Cave Survey. Ancient Mesoamerica 8:353-364.

Buck, $\mathrm{P}$.

1964. Arts and Crafts of Hawaii: Section X. War and Weapons. Museum Special Publication No. 45, Bishop Museum Press, Honolulu.

Carneiro, $\mathrm{R}$.

1970 A Theory of the Origin of the State. Science 169:733-738.

1981 The Chiefdom as Precursor to the State. In The Transition to Statehood in the New World, edited by G. Jones and R. Kautz, pp. 39-79. Cambridge University Press, Cambridge.

1990 Chiefdom-level Warfare as Exemplified in Fiji and the Cauca Valley. In The Anthropology of War, edited by J. Haas, pp. 171-189. Cambridge University Press, Cambridge.

Clerke, $\mathbf{J}$.

1967 Journal. In The Journals of Captain James Cook on His Voyages of Discovery, vol. 3: The Voyage of the Resolution and Discovery, 1776-1780, by J. Beaglehole, Parts 1 and 2. Cambridge University Press for the Hakluyt Society, Cambridge.

Collocott, E

1919 A Tongan Theogany. Folk Lore 30:234-238

Connah, $\mathrm{G}$.

1987 African Civilizations. Cambridge University Press, Cambridge.
Cordy, R.

1974a Cultural Adaptation and Evolution in Hawaii: A Suggested New Sequence. Journal of the Polynesian Society 83:180-191.

1974b The Tahitian Migration to Hawaii ca. 1100-1300A.D.: An Argument Against Its Occurrence. New Zealand Archaeological Association Newsletter 17:65-76.

1981 A Study of Prehistoric Social Change: The Development of Complex Societies in the Hawaiian Islands. Academic Press, New York.

2000 Exalted Sits the Chief. The Ancient History of Hawai' $i$ Island. Mutual Publishing, Honolulu.

Cox, J. H., and W. H. Davenport

1988 Hawaiian Sculpture. University of Hawaii Press, Honolulu.

D'Altroy, T.

1994 Factions and Political Development in the Central Andes. In Factional Competition and Political Development in the New World, edited by E. Brumfiel and J. Fox, pp. 171-188. Cambridge University Press, Cambridge.

Davenport, W.

1994 Pi'o. An Inquiry into the Marriage of Brothers and Sisters and Other Close Relatives in Old Hawai' $i$. University Press of America, Lanham, Maryland.

Davidson, J.

1992 The Prehistory of New Zealand. Longman Paul, Auckland.

Demarest, A

1978 Interregional Conflict and "Situational Ethics" in Classic Maya Warfare. In Codex Wauchope: A Tribute Roll, edited by M. Giardino, B. Edmonson, and W. Creamer, pp. 101-111. Human Mosaic, Tulane University, New Orleans.

Demarest, A., M. Omansky, C. Wolley, D. Van Tuerenhout, T. Inomata, J. Palka, and H. Escobedo

1997 Classic Maya Defensive Systems and Warfare in the Petexbatun Region: Archaeological Evidence and Interpretations. Ancient Mesoamerica 8:229-254.

De Montmollin, $\mathrm{O}$.

1989 The Archaeology of Political Structure: Settlement Analysis in a Classic Maya Polity. Cambridge University Press, New York.

Dixon, $\mathrm{B}$.

1987 Conflict Along the Southeast Mesoamerican Periphery: A Defensive Wall System at the Site of Tenampua. British Archaeological Reports 327(i):142-153.

Dixon, B., A. Carpenter, F. Eble, M. Major, and C. Mitchell 1995 Community Growth and Heiau Construction: Possible Evidence of Political Hegemony at the Site of Kaunolu, Lana'i, Hawai' i. Asian Perspectives 34:229-256.

Dixon, B., P. Conte, V. Nagahara, and W. Hodgins

1997 Upland Forest Periphery Subsistence and Settlement in the Ahupua'a of Kipapa, Nakaohu, and Nakaaha: A Preliminary Assessment. In Na Mea Kahiko o Kahikinui: Studies in the Archaeology of Kahikinui, Maui, edited by P. Kirch, pp. 28-43. Special Publication No. 1. Oceanic Archaeology Laboratory, University of California, Berkeley.

Dye, $T$.

1994 Population Trends in Hawai' i Before 1778. The Hawaiian Journal of History 28:1-21.

Earle, T.

1977 A Reappraisal of Redistribution: Complex Hawaiian Chiefdoms. In Exchange Systems in Prehistory, edited by T. Earle and J. Erickson, pp. 213-229. Academic Press, New York.

1980 Prehistoric Irrigation in the Hawaiian Islands: An Evaluation of Evolutionary Significance. Archaeology and Phys- 
ical Anthropology in Oceania 15:1-28

1987 Chiefdoms in Archaeological and Ethnohistorical Perspective. American Review of Anthropology 16:279-308.

1997 How Chiefs Come to Power: The Political Economy in Prehistory. Stanford University Press, Stanford.

Ellis, W. (Rev.)

1782 Authentic Narrative of a Voyage Performed by Captain Cook and Captain Clerke in His Majesty's Ships "Resolution" and "Discovery" . . 1776-80. Robinson, London.

1917 Narrative of a Tour Through Hawaii. Hawaiian Gazette Co., Honolulu.

Emerson, N.

1893 Long Voyages of the Ancient Hawaiians. Hawaiian Historical Society Papers 5:513.

Emory, K.

1924 The Island of Lanai. Bishop Museum Bulletin No. 12, Bishop Museum Press, Honolulu.

1968 East Polynesian Relationships as Revealed Through Adzes. In Prehistoric Culture in Oceania, edited by I. Yawata and Y. Sinoto, pp. 151-169. Bishop Museum Press, Honolulu.

Emory, K., and Y. Sinoto

1965 Preliminary Report of the Archaeological Excavations in Polynesia. Report prepared for the National Science Foundation, Anthropology Department, Bishop Museum, Honolulu.

Fash, W., Jr., R. Williamson, R. Larios, and J. Palka

1992 The Hieroglyphic Stairway and Its Ancestors: Investigations of Copan Structure 10L-26. Ancient Mesoamerica $3: 105-116$.

Feinman, G., and J. Neitzel

1984 Too Many Types: An Overview of Sedentary Prestate Societies in the Americas. In Archaeology Method and The ory, vol. 7, edited by M. Schiffer, pp. 39-102. Academic Press, New York.

Ferguson, R. B.

1998 Violence and War in Prehistory. In Troubled Times: Violence and Warfare in the Past, edited by D. Martin and D. Frayer, pp. 321-355. War and Society Series, Vol. 4. Gordon and Breach, Amsterdam, The Netherlands.

Fleming, M. F

1933 Old Trails of Maui. William and Mary Alexander Chapter, Daughters of the American Revolution.

Fornander, A.

1969 An Account of the Polynesian Race, its Origin and Migrations. Trubner, London.

Fox, J. G.

1996 Playing with Power: Ballcourts and Political Ritual in Southern Mesoamerica. Current Anthropology 37:483-509.

Fox, J. W.

1987 Mava Postclassic State Formation: Segmentary Lineage Migration in Advancing Frontiers. Cambridge University Press, New York.

Gifford, E.

1929 Tongan Society. Bishop Museum Bulletin No. 61. Bishop Museum Press, Honolulu.

Goldman, I.

1970 Ancient Polynesian Society. University of Chicago Press, Chicago.

Haas, J

1990 Warfare and the Evolution of Tribal Polities in the Prehistoric Southwest. In The Anthropology of War, edited by J. Haas, pp. 171-189. Cambridge University Press, Cambridge.

Haas, J., S. Pozorski, and T. Pozorski

1987 The Origins and Development of the Andean State.
Cambridge University Press, Cambridge.

Haleole, S. N.

1919 History of the Hawaiian Priesthood Called Hoomanamana. In Fornander Collection of Hawaiian Antiquities and Folk-lore, compiled by A. Fornander, edited and translated by T. Thrum, pp. 66-159. Memoirs of the Bernice P. Bishop Museum, Vol, 6, Honolulu.

Henry, T

1928 Ancient Tahiti. Bishop Museum Bulletin No. 48, Bishop Museum Press, Honolulu.

Higham, C.

1989 The Archaeology of Mainland Southeast Asia. Cambridge University Press, Cambridge.

Hommon, R.

1976 The Formation of Primitive States in Pre-Contact Hawai'i. Unpublished Ph.D. dissertation, Department of Anthropology, University of Arizona, Tucson.

1986 Social Evolution in Hawaii. In Island Societies: Archae ological Approaches to Evolution and Transformation, edited by P. Kirch, pp. 55-68. Cambridge University Press, Cambridge.

Houston, S.

1992 Classic Maya Politics. In New Theories on the Ancient Maya, edited by E. Danien and R. Sharer, pp. 65-70. The University Museum, University of Pennsylvania, Philadelphia.

1993 Hieroglyphs and History at Dos Pilas. University of Texas Press, Austin.

Hunt, T., and R. Holsen

1991 An Early Radiocarbon Chronology for the Hawaiian 'T'' Islands. Asian Perspectives 30:147-162.

1963 Fragments of Hawaiian History. Bishop Museum Special Publication No. 70, Bishop Museum Press, Honolulu.

Johnson, A. W., and T. K. Earle

1987 The Evolution of Human Societies. Stanford University Press, Stanford.

Johnston, K

1985 Maya Dynastic Territorial Expansion: Glyphic Evidence from Classic Centers of the Pasion River, Guatemala. In Fifth Palenque Round Table, 1983, Vol. VII, edited by M. Robertson and V. Fields, pp. 49-56. Precolumbian Art Research Institute, San Francisco.

Joyce, $\mathbf{R}$.

1991 Cerro Palenque: Power and Identity on the Maya Periphery, University of Texas Press, Austin.

Kalakaua, D.

1988 The Legends and Myths of Hawaii. Tuttle Press, New York.

Kamakau, S.

1961 Ruling Chiefs of Hawaii. Kamehameha Schools Press, Honolulu.

1964 Ka Po'e Kahiko: The People of Old. Bishop Museum Special Publication No. 51, Bishop Museum Press, Honolulu.

1976 The Works of the People of Old. Bishop Museum Special Publication No. 61, Bishop Museum Press, Honolulu.

Kame'eleihiwa, L.

1992 Native Land and Foreign Desires. Bishop Museum Press, Honolulu.

Keeley, L. H.

1996 War Before Civilization: The Myth of the Peaceful Savage. Oxford University Press, Oxford.

Kelly, M.

1986a The Concept of Asylum. In The Natural and Cultural History of Hnaunau, Kona, Hawai' $i$. Departmental Report 
Series 86.2, edited by E. Bryan and K. Emory, pp. 137-150. Department of Anthropology, Bishop Museum, Honolulu. 1986b List of Pu'uhonua. In The Natural and Cultural History of Hnaunau, Kona, Hawai'i. Departmental Report Series 86.2, edited by E. Bryan and K. Emory, pp. 150-162. Department of Anthropology, Bishop Museum, Honolulu.

Kennedy, J., and J. Brady

1997 Into the Netherworld of Island Earth: A Re-evaluation of Refuge Caves in Ancient Hawaiian Society. Geoarchaeology 12:641-655.

Kirch, P.

1984 The Evolution of Polynesian Chiefdoms. Cambridge University Press, New York.

1985 Feathered Gods and Fishooks. University of Hawaii Press, Honolulu.

1990a Regional Variation and Local Style: A Neglected Dimension in Hawaiian Prehistory. Pacific Studies 13:41-54.

1990b The Evolution of Sociopolitical Complexity in Prehistoric Hawaii: An Assessment of the Archaeological Evidence. Journal of World Prehistory 4:311-345.

Klieger, $\mathrm{P}$.

1995 Na Maka o Hlawa. Bishop Museum Technical Report No. 7, Bishop Museum Press, Honolulu.

Kolb, M. J.

1991 Social Power, Chiefly Authority, and Ceremonial Architecture, in an Island Polity, Maui, Hawaii. Unpublished Ph.D. dissertation, Department of Anthropology, University of California, Los Angeles.

1992 Diachronic Design Changes in Heiau Temple Architecture on the Island of Maui, Hawai'i. Asian Perspectives 31:9-37.

1994 Monumentality and the Rise of Religious Authority in Precontact Hawai'i. Current Anthropology 34:521-547.

1999 Pig Sacrifice and the Archaeology of Ritual in the Hawaiian Kingdom. In Complex Polities in the Ancient Tropical World, Archaeological Papers of the American Anthropological Association 9, edited by E. A. Bacus and L. J. Lucero, pp. 89-107.

Kolb, M. J., P. Conte, and R. Cordy

1997 Kula: The Archaeology of Upcountry Maui in Waiohul and Keokea. State of Hawaii Historic Preservation Division. Wailuku.

Kolb, M., J., and G. Murakami

1994 Cultural Dynamics and the Ritual Use of Woods in PreContact Hawai'i. Asian Perspectives 33:57-78.

Kolb, M., and E. Radewagen

1997 Na Heiau o Kahikinui: The Temples of Kahikinui. In Na Mea Kahiko o Kahikinui: Studies in the Archaeology of Kahikinui, Maui, edited by P. Kirch, pp. 61-77. Special Publication No. 1. Oceanic Archaeology Laboratory, University of California at Berkeley.

Kristiansen, $\mathrm{K}$

1997 Europe before History. Cambridge University Press, Cambridge

Kuykendall, R.

1968 The Hawaiian Kingdom, volume 1: 1778-1854. University of Hawaii Press, Honolulu.

Ladd, E.

1969 The Great Wall Stabilization: Salvage Report. In Archaeology on the Island of Hawaii, edited by R. Pearson, pp. 133-162. Social Science Research Institute, Asian and Pacific Archaeology Series No. 3. University of Hawaii, Honolulu.

1985 Hale o Keawe Archaeological Report. In Archaeology at Pu'uhonua o Honaunau National Historic Park. Western Archaeological and Conservation Center Publications in
Anthropology No. 33, National Park Service, Tucson.

1986 Ki'ilae Village Test Excavations. In Archaeology at Pu'uhonua o Honaunau National Historical Park. Western Archaeological and Conservation Center Publications in Anthropology No. 34, National Park Service, Tucson.

1987 Excavations at Site A-27. In Archaeology at Pu'uhonua o Honaunau National Historical Park. Western Archaeological and Conservation Center Publications in Anthropology No. 43, National Park Service, Tucson.

Laval, $\mathrm{H}$.

1938 Mangareva. Braine-le-comte, Maisons des Peres des Sacres-Coeurs, Belgique.

Lyons, C.

1875 Land Matters in Hawaii, volume I. The Islander. Honolulu.

Maschner. H. D. G., and K. L. Reedy-Maschner

1998 Raid, Retreat, Defend (Repeat): The Archaeology and Ethnohistory of Warfare on the North Pacific Rim. Journal of Anthropological Archaeology 17:19-51.

Major, M., F. Stone, and B. Dixon

1992 A Burial Report Concerning the Pohoiki No. 2 Transmission Line Corridor, Puna District, Island of Hawai'i. Anthropology Department, Bishop Museum, Honolulu.

Malo, D.

1951 Hawailan Antiquities. Translated by N. Emerson. Bishop Museum Special Publication No. 2, Honolulu.

Masse, B., L. Carter, and G. Somers

1991 Waha'ula Heiau: The Regional and Symbolic Context of Hawai'i Island's "Red Mouth" Temple. Asian Perspectives 30:19-56.

Matheny, R.

1986 Early States in the Maya Lowlands During the Late Preclassic Period: Edzna and El Mirador. In City States of the Maya: Art and Architecture, edited by E. Benson, pp. 1-44. Rocky Mountain Institute for Pre-Columbian Studies, Denver.

McCoy, P.

1976 Easter Island Settlement Patterns in the Late Prehistoric and Protohistoric Periods. International Fund for Monuments, Easter Island Committee, Bulletin No. 5.

Menzies, A.

1920 Hawaii Nei 128 Years Ago, edited by W. Wilson. New Freedom Press, Honolulu.

Metraux, A.

1971 Ethnology of Easter Island. Bishop Bulletin No. 160, Bishop Museum Press, Honolulu.

Mills, $\mathrm{P}$.

1996 Transformations of a Structure: The Archaeology and Ethnohistory of a Russian Fort in a Hawaiian Chiefdom, Waimea, Kaua'i. Unpublished Ph.D. dissertation, Department of Anthropology, University of California, Berkeley.

Monks, S. J.

1997 Conflict and Competition in Spanish Prehistory: The Role of Warfare in Societal Development from the Late Fourth to Third Millennium B.C. Journal of Mediterranean Archaeology 10:3-32.

Nelson, $\mathrm{O}$

1925 Legends of Samoa. Journal of the Polynesian Society $34: 24-42$.

Obeyesekere, $\mathrm{G}$.

1992 The Apotheosis of Captain Cook. Princeton University Press and Bishop Museum Press, Honolulu.

O'Farrall, W.

1904 Native Stories from Santa Cruz and Reef Islands. Journal of the Royal Anthropological Institute of Great Britain and Ireland 34:223-233. 
Pauketat, T. R.

1994 The Ascent of Chiefs. The University of Alabama Press, Tuscaloosa.

Pukui, M., and S. Elbert

1971 Hawaiian Dictionary. University of Hawaii Press, Honolulu.

Puleston, D., and D. Callender

1967 Defensive Earthworks at Tikal. Expedition 9:40-48.

Redmond, E.

1994 External Warfare and the Internal Politics of Northern South American Tribes and Chiefdoms. In Factional Competition and Political Development in the New World, edited by E. Brumfiel and J. Fox, pp. 44-54. Cambridge University Press, Cambridge.

Rice, D., and P. Rice

1981 Muralla de Leon: A Lowland Maya Fortification. Journal of Field Archaeology 8:271-288.

Sahlins, $M$.

1985 Islands in History. University of Chicago Press, Chicago.

1992 Anahulu: The Anthropology of History in the Kingdom of Hawai' $i$. vol. 1, edited by P. Kirch and M. Sahlins. University of Chicago Press, Chicago.

Samwell, D.

1967 Journal. In The Journals of Captain James Cook on his Voyages of Discovery, vol. 3, the Voyage of the Resolution and Discovery, 1776-1780, by J. Beaglehole, parts 1 and 2, Cambridge University Press for the Hakluyt Society, Cambridge.

Schele, L., and M. Miller

1986 The Blood of Kings: Dynasty and Ritual in Maya Art. George Braziller, Fort Worth.

Schoenfelder, J. W.

1992 The Politics of Absolution: Restricted Access and Ritual Subordination at the Hawaiian Pu'uhonua. Unpublished Master's thesis, Department of Anthropology, University of California, Los Angeles.

Schilt, A.

1984 Subsistence and Conflict in Kona, Hawai'i: An Archaeological Study of the Kuakini Highway Realignment Corridor. Department of Anthropology Report 84-1, Bishop Museum, Honolulu.

Simons, A., and D. Gosser

2001 Conflict and Exchange among the Salado of Tonto Basin. In Deadly Landscapes: Case Studies in Prehistoric Southwestern Warfare, edited G. Rice and S. A. LeBlanc, pp. 219-238. University of Utah Press, Salt Lake City.

Sinoto, Y.

1970 An Archaeologically Based Assessment of the Marquesas Islands as a Dispersal Center in East Polynesia. In Studies in Oceanic Culture History, edited by R. Green and M. Kelly, pp. 105-132. Pacific Anthropological Records No. 11, Anthropology Department, Bishop Museum, Honolulu.

Spriggs, M., and A. Anderson

1993 Late Colonization of East Polynesia. Antiquity 67:200-217.

Stark, T. M., P. B. Griffin, C. Phoeurn, J. Ledgerwood, M. Dega, C. Mortland, N. Dowlin, J. M. Bayman, B. Sovath, T. Van, C. Chamroeun, and K. Latinis.
1999 Results of the 1995-1996 Archaeological Field Investigations at Angkor Borei, Cambodia. Asian Perspectives 38:7-36.

Sterling, E., and C. Summers

1978 Sites of Oahu. Department of Anthropology. Bishop Museum, Honolulu.

Stokes, J.

1991 Heiau of the Island of Hawai'i. A Historic Survey of Native Hawaiian Temple Sites. Bishop Museum Bulletin in Anthropology No. 2. Bishop Museum Press, Honolulu.

Stone, A.

1995 Images from the Underworld: Naj Tunich and the Tradition of Maya Cave Painting. University of Texas Press, Austin.

Summers, C.

1971 Molokai: A Site Survey. Pacific Anthropological Records No. 14. Bishop Museum Press, Honolulu.

Tuggle, D., and M. Spriggs

2001 The Age of the Bellows Dune Site O18, O'ahu, Hawai'i, and the Antiquity of Hawaiian Colonization. Asian Perspectives 39:165-188.

Tuggle, D., and M. Tomonari-Tuggle

1980 Prehistoric Agriculture in Kohala, Hawai'i. Journal of Field Archaeology 7:297-312.

Turner, $\mathrm{G}$

1861 Nineteen Years in Polynesia: Missionary Life, Travels, and Researches in the Islands of the Pacific. J. Snow, London.

Valeri, V.

1985 Kingship and Sacrifice: Ritual and Society in Ancient Hawaii. Translated by P. Wissing, University of Chicago Press, Chicago.

Walker, W.

1931 Archaeology of Maui. Bishop Museum Library, Honolulu.

Webster, D.

1976 Defensive Earthworks at Becan, Campeche, Mexico. Middle American Research Institute, Publication No. 41, Tulane University, New Orleans.

1977 Warfare and the Evolution of Maya Civilization. In The Origins of Maya Civilization, edited by R. Adams, pp. 335-372. University of New Mexico Press, Albuquerque.

1985 Warfare and the Evolution of the State.American Antiquity 40:464-70.

1993 The Study of Maya Warfare: What It Tells Us About the Maya and What It Tells Us About Maya Archaeology. In Lowland Maya Civilization in the Eighth Century A.D., edited by J. Sabloff and J. Henderson, pp. 415-444. Dumbarton Oaks, Washington D.C.

1998 Warfare and Status Rivalry: Lowland Maya and Polynesian comparisons. In Archaic States, edited by G. Feinman, and J. Marcus J., pp. 331-352. School of American Research, Santa Fe.

2000 The Not So Peaceful Civilization: A Review of Maya War. Journal of World Prehistory 14:65-119.

Received November 19, 2001; Revised March 6, 2002,

Accepted March 7, 2002. 